\title{
The influence of e-portfolio toward the process and the quality of students`translation
}

\author{
Maya Rahmawati \\ mayarahmawati.rahmawati@gmail.com \\ Universitas Singaperbangsa Karawang \\ Jl. H.S Ronggowaluyo Puseurjaya Teluk Jambe Timur Karawang Timur, Indonesia
}

Putri Kamalia Hakim

putrikamaliahakim@gmail.com

Universitas Singaperbangsa Karawang

Jl. H.S Ronggowaluyo Puseurjaya Teluk Jambe Timur Karawang Timur, Indonesia

Received: January 19, 2018; Accepted: September 21, 2018; Published: September 30, 2018

\begin{abstract}
This study is aimed at gaining an understanding of the influence of e-portfolio on the process and quality of translation (acceptability, accuracy, and readability) of students and how e-portfolio affects the process and quality of student translations. The method used in this research is sequential explanatory design. The subjects of this study are the third-year students of English Education Department at Universitas Singaperbangsa Karawang (UNSIKA) Indonesia who took translation practice course. The quantitative data are taken from the pre-test and post-test results. The qualitative data are gained from questionnaire and interview. After analysis, it is found that e-portfolio influenced the students' translation ability where the value is Sig. $=0.001<\alpha=$ 0.05 . It was discovered that $82 \%$ students achieved higher score in acceptability. Meanwhile, 62\% students achieved higher score in accuracy, and only 56\% students achieved higher score in readability. In terms of translation process, eportfolio helps students track their progress, give and receive feedback from various participants, as well as have virtual room to sort their works which are easily accessible.
\end{abstract}

Keywords: e-portfolio, assessment, translation, translation process, translation quality 
How to cite this paper: Rahmawati, M., \& Hakim, P. K. (2018). The influence of e-portfolio toward the process and the quality of students` translation. Journal on English as a Foreign Language, 8(2), 202-218. doi:http://dx.doi.org/10.23971 ßefl.v8i2.751

DOI: http://dx.doi.org/10.23971/jefl.v8i2.751

Some translation experts as a matter of fact put a great emphasize on translation process in their theory. Translation is a process of the exchange of the whole text from the source language into the target language (Farahani, 2013, p. 115). According to the functionalist approach, translation as an act of communication in which the process of analyzing the source text should consist of analyzing both the extratextual and intratextual factors of the text. It affirms that translation cannot be carried out in one single step. Therefore, considering the importance of translation steps the students have to take in the process, the assessment should not only focus on the end product but also on the process. It should covers the students' learning outcome as well as the process to gain complete description of their competence.

In the English Education Department of Universitas Singaperbangsa Karawang (UNSIKA) Indonesia, translation has been one of the supplementary subjects which covers both theory and practice. Dealing with translation theory, there is no significant constraint found in the process of teaching and evaluating it. However, from the observation during the teaching and learning process, some problems arised when evaluating translation skill in translation practice subject. It is due to the fact that translation practice takes translation as a skill rather than science which requires prolonged process of practice to attain a particular level of mastery. Therefore, for translation practice subject, the end product is not solely the main learning outcome.

In fact, in the translation classroom it showed that students are encouraged to actively participate in giving their opinions about the closest equivalence of some words. They are motivated not to be reluctant to get engaged in the learning process for there is no perfect translation, but equivalent translation which is apropriate with its communicative function. Their skill will improve as they practice translation from time to time. Thus, it would be unfair for the students when the long process they have gone through is not proportionally assessed.

The aformentioned facts show that translation for undergraduate classroom requires more than just a conventional assessment. Traditional assessment tends to be results-oriented, summative, not contexttually 
communicative, does not provide learners with considerable feedback, has rigid time formats, and promote extrinsic motivation only (Combee, Purmensky \& Davidson, 2012; Brown, 2013). This kind of assessment is considered insufficient to assess translation course whose $90 \%$ of the learning activity involves practice. In researchers' class, students are required not only to translate the text but also to analyze it before translating, solve every translation problem, and evaluate their translation.

The course needs a kind of assessment which enables teachers to link students assessment result and the instructional process. To solve the issue, one potential assessment solution is through alternative assessment (Ghoorchaei, Tavakoli, \& Ansari, 2010), and the alternative assessment is portfolio assessment. Moreover, Chitpin (2003) states that portfolio assessment is suited not only to evaluate students' progress but also their final achievement. Portfolio is a compilation of students' works that evaluates quality over time (Brown, 2003; Chitpin, 2003).

According to Coombe, Troudi, and Al-Hamly (2012), alternative assessement uses a kind of task type which evaluate the students on what they integrate and produce rather than on what they are able to recall and reproduce. Thus, you might not find short-answer questions, true-false questions, or multiple-choice questions in alternative assessment. Such assessments are replaced by more authentic and meaningful ones which are considered easier to be integrated into instructional process (Czura, 2013).

There are several types of commonly used portfolios in education. One type of portfolio that has now begun to be widely used is the electronic portfolio. The electronic portfolio allows students to include their assignments or work in a multimedia format. The similarity of the electronic portfolio with the traditional portfolio lies in the reflection activities that must exist in the learning process. As Dudeney and Hockley (2007, p. 119) stated that the eportfolio may cover reflections on the learning itself. Nevertheless, electronic portfolios can be considered superior to traditional portfolios. In the midst of today's rapid technological advances, electronic portfolios are capable of delivering long-term benefits over traditional portfolios. Some of the advantages of electronic portfolios include: (1) with an increasingly widespread internet reach, it makes students easier to learn and discuss anywhere and anytime; (2) electronic portfolios may be used by students to apply for job as authentic evidence of works they have created during college study; and (3) it is eco-friendly for not using paper.

With some of the advantages of electronic portfolios as described, researchers assumed that this medium is excellent for as a means of learning and assessment. It allows learners to share ideas and opinions actively in the 
process of translation without wasting much time, money, and stationery. This is apt to be used in translation practice course to get the learners actively engaged in the learning process.

Based on the above explanation, the authors decided to study the effect of the use of e-portfolio as a tool to assess the process and quality of students' translation in translation courses. This study specifically investigates a productoriented portfolio. Each portfolio must still provide information about the students' progress track record over time despite being product-oriented. The product-oriented portfolio was chosen because this study aims to see whether its use has an impact on improving the quality of students' translations.

The purpose of this research is to gain an understanding of the effect of e-portfolio on the process and quality of translation (acceptability, accuracy, and readability) of students and how e-portfolio affects the process and quality of student translations. This research is expected to provide benefits both theoretically and practically. Theoretically, this research is expected to be able to develop theories of translation focusing on translation teaching specifically on the influence of e-portfolio on the students' process and quality of translation (acceptability, accuracy, and readability) and how e-portfolio affects the process and quality of student translations. While in practical terms, this research is expected to provide additional information for learners and lecturers about an objective assessment that can measure all components of the process and learning outcomes at once so as to describe the authentic ability of learners.

\section{METHOD}

Mix method is used in this research to get better understanding about the problem. Creswell (2012) argued that mix method focuses on collecting, analyzing, and mixing quantitative and qualitative data. One of the major types of the method, the sequential explanatory design, is done in this research by collecting and analyzing the quantitative data taken from the pre-test and posttest results then followed by collecting and analyzing the qualitative data, which are the questionnaire and interview results. The purpose of the method is to use qualitative approach to explain quantitative result (Creswell, 2012).

The subjects of this study are the third-year students of English Education Department at UNSIKA Indonesia who took translation practice course. To get the quantitative data, the writer uses one group pre-test post-test design. Therefore there is only one experimental class without any control class. The following is the illustration of the design:

O1 $\quad X \quad 02$

Explanation:

Journal on English as a Foreign Language, 8(2), 202-218

Copyright (C) 2018 by JEFL, p-ISSN 2088-1657; e-ISSN 2502-6615 
O: Pre-test and post-test (the ability to translate Indonesian language text into English)

X: Treatment (portfolio-based learning and assessment)

The subjects are given treatment in the form of the use of e-portfolio in the process and assessment of Indonesian-English translation course. One class is selected as an experimental class that receives treatment in the form of eportfolio-based learning and assessment. The population of this research is all students of 6th semester of English Education Department of UNSIKA Indonesia. The researchers took one class as a sample by purposive sampling as an experimental class. The class taken is class $6 \mathrm{~A}$ with 23 students.

The data were collected through administering pre-test and post-test, distributing questionnaire and doing interviews after the treatment ended. The quantitave data were gained from pre-test and post-test score. In those tests, the students are requested to translate a text in Indonesian language about Montessori Education, Pendidikan Berbasis Montessori, Apakah Itu?, into English language. This text was used for pre-test and post-test. The pre-test is used to determine the initial ability to translate, while post-test was used to determine to what extent has the e-portfolio influenced the students' learning outcomes. To discover the quality of students' translation, the author assesses the student's translation based on four criteria such as accuracy, readability, and acceptablity using the rubric that has been determined.

Questionnaires were distributed consisting of 25 items likert questions, 12 dichotomous questions, and 3 open-ended questios. The test and non-test instruments were validated by a competent expert. The validity measured is the content validity. It was measured to make sure that the items consisted in the instruments met what the research is supposed to discover. To recheck the information taken from the questionnaires, the researchers did unstructure indepth interview with the students. The writer gained the mean score and standard deviation through pre-test and post-test and found the difference in mean of both tests. The difference in means test is used to prove whether the students' initial and final competence differ significantly. The normality test analysis was conducted to determine if the data is normally distributed. The normality test of pre-test-post-test score was performed using Shapiro-Wilk test using SPSS 17 program. Furthermore, the qualitative data, the students` work were analyzed by the rater using rubric. The students` scores, their correct and incorrect translations were studied by correlating them with the interview and questionnaire results. 


\section{FINDINGS}

The findings were obtained from pretest and posttest score, questionnaire, and in-depth interview. Between the pretest and posttest, students were given treatment by assessing their learning using e-portfolio. The e-portfolio used in this research is Trello. It is a web-based social media appropriate for collaborative project. Students were required to post their assignment or practice, complement their translation work with suplementary sources, give feedback for their peers, receive feedback both from their peers and lecuturer. This process was carried out during the whole semester. At the end of the course, students were evaluated based on what they had presented in their e-portfolio.

This section presents the effect of e-portfolio use on the quality of students' translation and their process of translating Indonesian texts into English. The discussion is divided into two parts, namely the section on the effect of e-portfolio on the ability to translate the results seen through the quality of translation in the aspect of accuracy, readability, and acceptability; while the other part is about its effect on the process of students in translating. To determine the effect of e-portfolio on translating ability, the researcher compares the score of the student's translation results regarding its accuracy, readability, and acceptability aspects. In pre-test and post-test students are required to translate a non-fiction text entitled Pendidikan Berbasis Montessori, apakah itu? This study used one group pre-test post-test study; therefore there is only one experimental class without any control class. Nevertheless, this study examines in depth each of the criteria included in the component of the translation ability, such as accuracy, readability, and acceptability.

\section{The Influence of E-Portfolio toward Students' Translation Work}

To examine the effect of using e-portfolio on translation ability, the researchers examined the quality of students' translation regarding its accuracy, readability, acceptability, and consistency through pre-test and post-test. Quantitative data were obtained through translation test at the beginning and the end of the instruction. The research subject initially consist of 30 students, but only 17 students taken as sample as the rest of them only attended one of the two tests. The mean score and standard deviation were gained through pretest and post-test. Table 1 demonstrates the description of the research result.

Based on the Table 1, it was found that the difference in mean between pre-test and post-test is 13.2353 . It means that after being taught and assessed using e-portfolio, there is an improvement in students' post-test score. It proves that e-portfolio assessment positively contributes to the improvement of students' translation skill. The next step is pre-test and post-test score analysis

Journal on English as a Foreign Language, 8(2), 202-218

Copyright @ 2018 by JEFL, p-ISSN 2088-1657; e-ISSN 2502-6615 
using difference in means test. This test aims to prove whether the students' initial and final competence differ significantly. Before analyzing the data, normality test analysis was conducted. This is used to determine which statistic test to be performed. If the data is normally distributed, then parametric statistic test (t-test) is used. If otherwise, then the Wilcoxon Signed Rank Test of non-parametric test is used.

Table 1. Statistical Descriptive of Pre-test and Post-test

\begin{tabular}{cccccc}
\hline Test & $\mathrm{N}$ & Min & Max & Mean & Std. Deviation \\
\hline Pre-test & 17 & 17.00 & 78.00 & 39.2941 & 15.16890 \\
\hline Post-test & 17 & 32.00 & 80.00 & 52.5294 & 16.65877 \\
\hline
\end{tabular}

The normality test of pre-test-post-test score is performed using ShapiroWilk test using SPSS 17 program. This test is used because the data is small $(n<30)$. Whether the hypothesis is formulated as follow:

$\mathrm{H}_{0}$ : The data is normally distributed

$\mathrm{H}_{1}$ : The data is not normally distributed

The criteria of the test is that $\mathrm{H}_{0}$ is rejected if Sig. $<\alpha=0,05$. The result of this normality test is presented in the Table 2 .

Table 2. Normality Test of Pre-test and Post-test Score

\begin{tabular}{ccccccc}
\hline \multirow{2}{*}{ Test } & \multicolumn{3}{c}{ Kolmogorov-Smirnov } & \multicolumn{3}{c}{ Shapiro-Wilk } \\
\cline { 2 - 7 } & Statistic & Df & Sig. & Statistic & df & Sig. \\
\hline Pre-test & 0.147 & 17 & 0.200 & 0.940 & 17 & 0.318 \\
\hline Postest & 0.173 & 17 & 0.187 & 0.900 & 17 & 0.069 \\
\hline
\end{tabular}

The Table 2 shows that the pre-test and post-test score of translation test has value of Sig. $>\alpha=0,05$, for which $\mathrm{H}_{0}$ is rejected. This proves that pre-test and post-test score of translation is not normally distributed.

Since the data of pre-test and post-test score is not normally distributed, the non-parametric statistic of Wilcoxon paired sample test was performed using SPSS 17. The hypothesis proposed in this research is that there is an effect of eportfolio based assessment on the students' translation ability. To examine the proposed hypothesis, the statistical hypothesis is formulated as follow:

$\mathrm{H}_{0}: \mu_{1}=\mu_{2}$; There is no different result of translation test score before and after the implementation of e-portfolio-based assessment 
$\mathrm{H}_{1}: \mu_{1} \neq \mu_{2}$; There is different result of translation test score before and after the implementation of e-portfolio-based assessment

$\mu_{1}=$ Average score of translation ability before the implementation of eportfolio-based assessment

$\mu_{2}=$ Average score of translation ability after the implementation of eportfolio-based assessment

The Table 3 shows the result of Wilcoxon Signed Rank Test.

Table 3. Wilcoxon Signed Rank Test

\begin{tabular}{cc}
\hline Statistik Uji & Postest - Pre-test \\
\hline$Z$ & -3.388 \\
\hline Asymp. Sig. (2-tailed) & 0.001 \\
\hline
\end{tabular}

According to the Table 3, the value obtained is Sig. $=0.001<\alpha=0.05$. This proves that $\mathrm{H}_{0}$ is rejected which means the implementation of e-portfolio influences the students' translation ability.

\section{Translation Quality}

\section{Accuracy Aspect}

The Graph 1, containing the comparison between the scores obtained during pre-test and post-test, demonstrates that $62 \%$ of the total number of students has improved their translation ability in accuracy aspect after using the e-portfolio. Furthermore, $18 \%$ of students got the same score during pre-test and post-test.

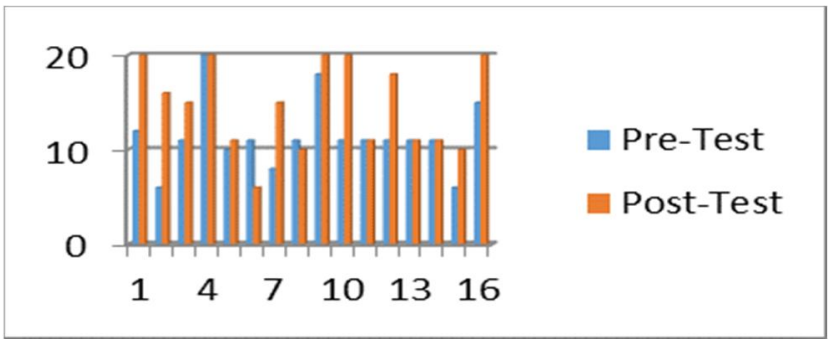

\section{Graph 1. Score in Accuracy}

It can be inferred that the increasing score obtained by students is significant in accuracy aspect. This indicates that students can accurately communicate the meaning of the source language; no text content is omitted, added or subtracted. As in the example of the translation text below (see Image 1 ), at first student ignored the title of the text and had not translated it in the pre-test but during the post-test he did not forget to translate it. 


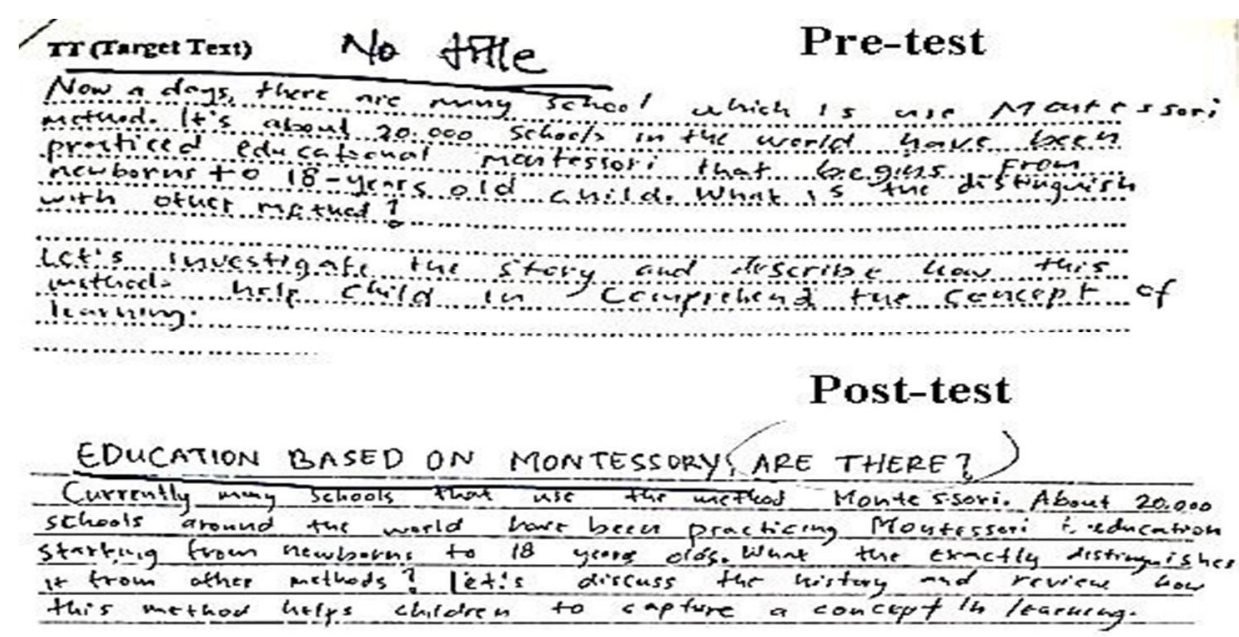

Image 1. Fragment Sample for Accuracy

This finding is in line with the results of the perception test through questionnaires and interviews. Based on the results of questionnaires and interviews, it is discovered that the use of e-portfolio affects the accuracy of their translation though not directly. Students further explained that by easily accessing a collection of translated and revised works provided by tutors and peers; it made them easier to look for omissions or addition of idea in their translation. Moreover, since the students producing translations by typing, they could always have more time to make sure that the entire ideas of the source text were translated well. Furthermore, the improvement on accuracy is also obtained because all student work results can be viewed and accessed by all member of the class. Thus, students feel the need to publish their best work in e-portfolio because the use of e-portfolio allows all students to see the results of their peers' work.

For certain students, however, effect of e-portfolio on the accuracy of student translation is not always positive since as many as $20 \%$ of the students get lower grades in post-test, after using e-portfolio. Researchers suspected that this is caused by overcorrection. During the use of e-portfolio, it appears that students gave an excessive portion in correcting errors in terms of accuracy. Their overly cautious attitude in translating precisely causes them not to accurately translate the text. The majority of students who make this mistake are those who belong to high achiever in class.

\section{Readability Aspect}

The Graph 2, containing the comparison between the scores obtained during pre-test and post-test, demonstrates that $56 \%$ of the total number of students has improved their translation ability in readability after using the e- 
portfolio. Furthermore, $18 \%$ of students had constant score for pre-test and post-test. None of the students experienced a decline in the readability aspect of the post-test. It can be concluded that e-portfolio use has a positive impact on the translation score in terms of readability aspect.

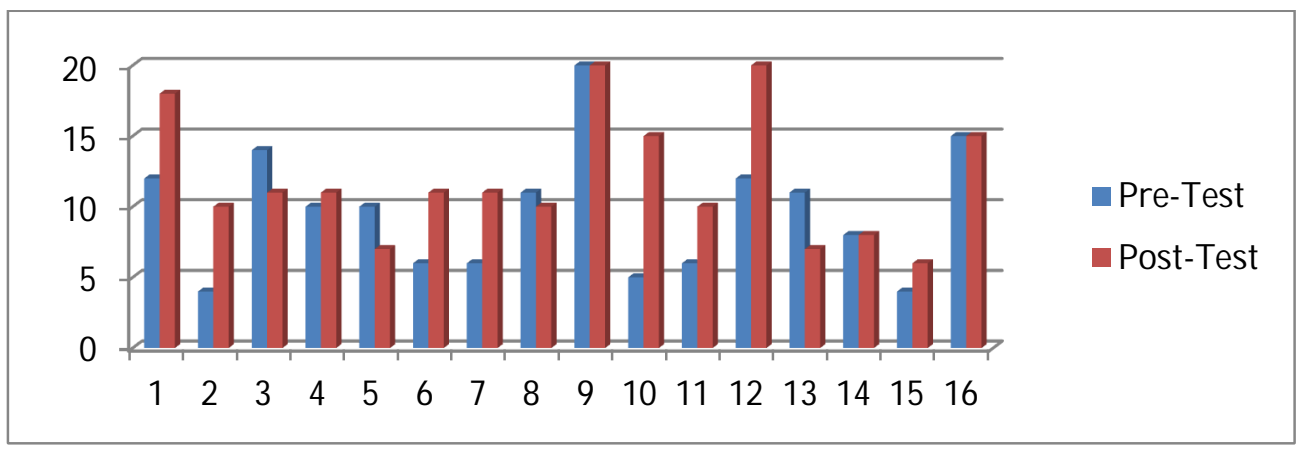

Graph 2. Score in Readability

As shown in the translation fragment (see Image 2), students can produce more readable sentences as they work on post-test.

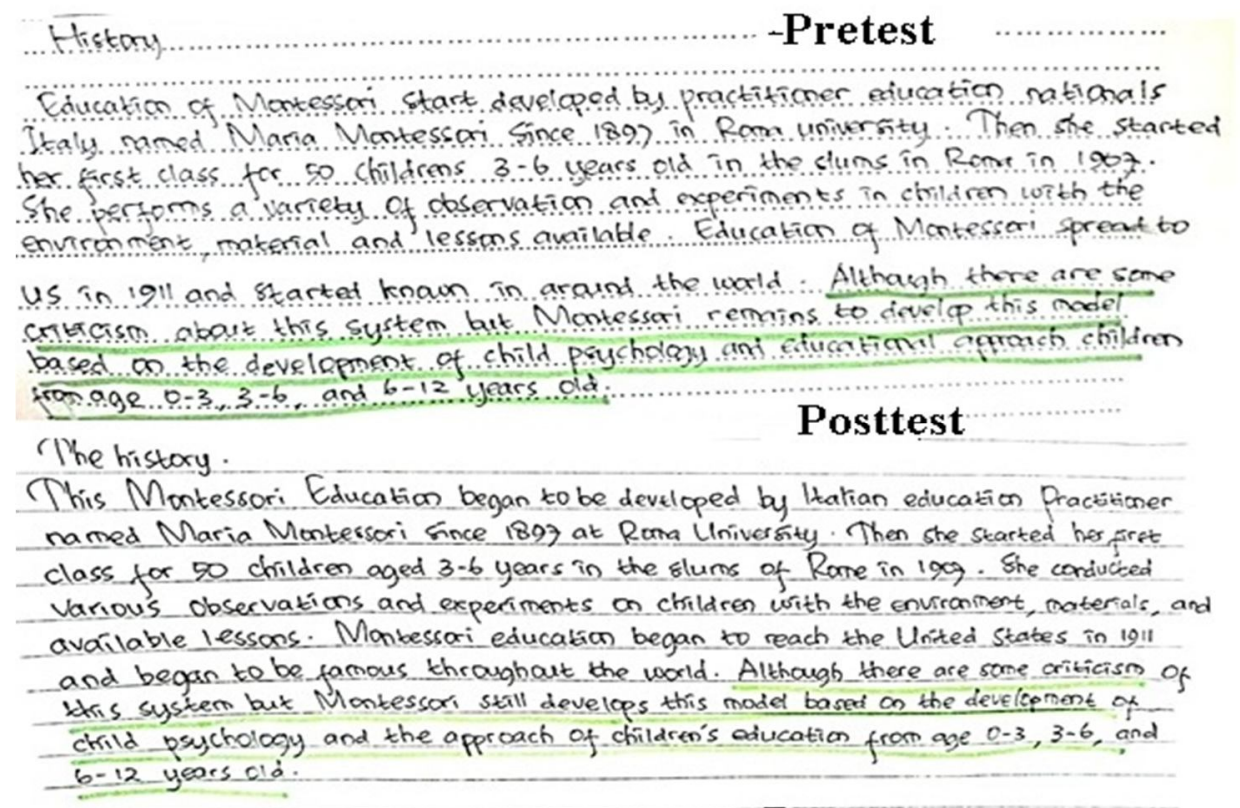

Image 2. Fragment Sample for Readability

Referring to the Image 2, it is identified that initially students could not arrange the word and choose the word well during pre-test. However, they eventually could choose and use words contextually and grammatically appropriate during post-test. During pre-test he translated the "child education approach" originally as "educational approach children", but at the post-test he translated it as "the approach of children's education". However, according to

Journal on English as a Foreign Language, 8(2), 202-218

Copyright @ 2018 by JEFL, p-ISSN 2088-1657; e-ISSN 2502-6615 
the perception of students obtained through interviews and questionnaires, it is discovered that the use of e-portfolio had only influenced the score regarding readability indirectly. With the ease of accessing a collection of translations, feedback from tutors and peers, the ease of writing translations and other things ultimately help them produce translations with higher levels of readability. They are able to produce a translation with words, terms, phrases, or clauses and sentences that are easy to understand and grammatically correct.

\section{Acceptability Aspect}

The Graph 3, containing the comparison between the scores obtained during pre-test and post-test, demonstrates that $82 \%$ of the total number of students gained an increase in acceptability score after using e-portfolio. Furthermore, $18 \%$ of students achieved constant score during pre-test and posttest. None of the students had lower score in the aspect of acceptability during post-test.

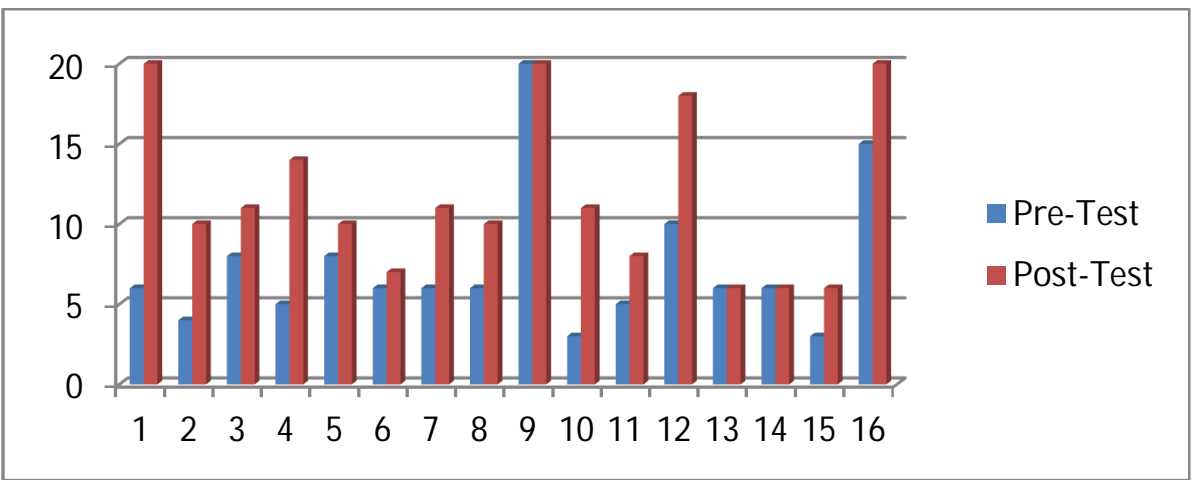

Graph 3. Score in acceptability

As shown in the translation fragment (see Image 3), students could produce more acceptable sentences during post-test. The Image 3 proves that initially the student could not translate the source text naturally or the translation seemed too literal. However, he could finally produce a more reasonable and acceptable translation. On the pre-test, the student translated "Sekitar 20.000 sekolah di seluruh dunia" as "approximate 20,000 schools in a whole world," but at the post-test he translated it as "about 20,000 schools in a whole world". Originally the student translated "around" as "approximate" which is an adjective then he replaced it with "about" which is an adverb. 


\section{Pretest}

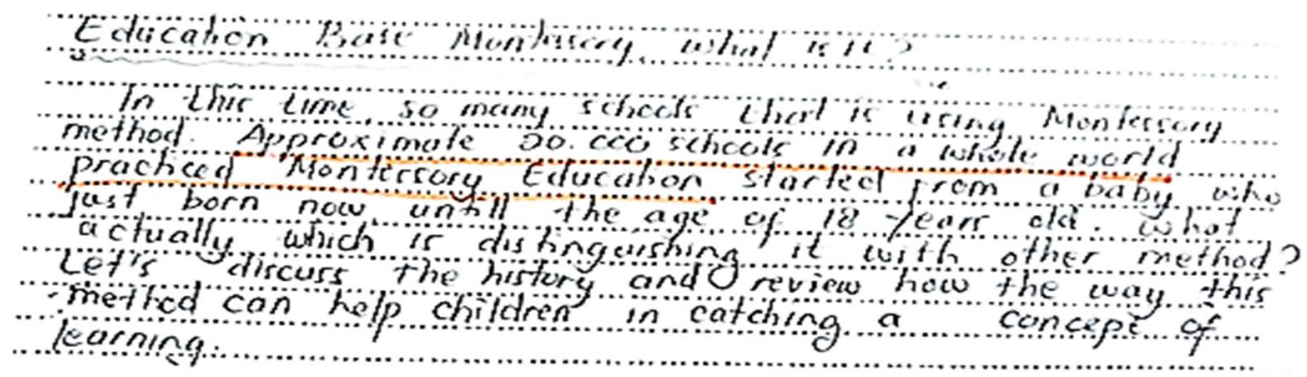

\section{Pöstèst}

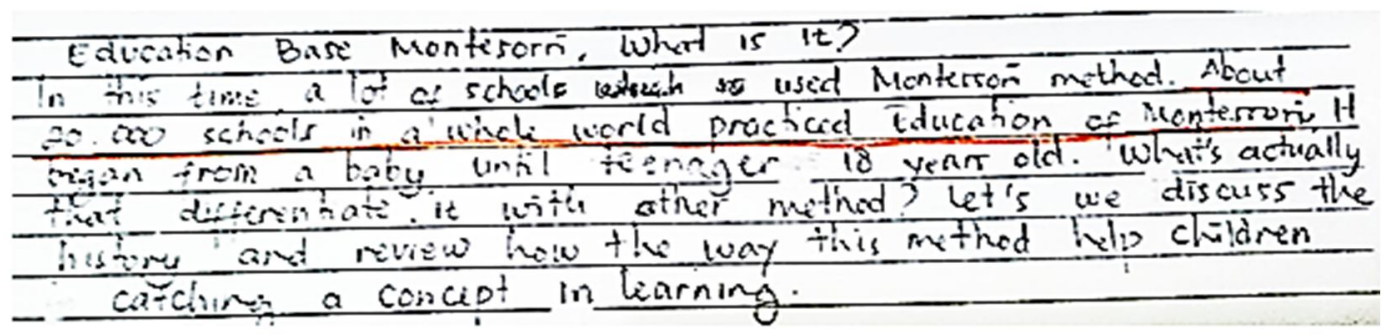

Image 3. Fragment Sample for Acceptability

This is in accordance with the results of questionnaires and interviews. Students feel that by using e-portfolios they can better understand the meaning of the source text so that their translations can be modified to become more natural. They feel they were more encouraged to work harder to translate since their translation work will be read and commented by their colleagues. The practicality of modifying the results of the translation through computer made them more excited and work better. With e-portfolio, writing and editing translation becomes easier. In the end, they could more easily gain higher score in the aspect of acceptability. As could be seen in the above translation fragments, students could produce sentences with higher acceptability score than when they were working on a pre-test.

\section{Translation Process}

To see the effect of the use of e-portfolio on the process of translating, the researcher studied the perception of the students on the learning process of Indonesia to English translation course using e-portfolio as assessment tool. Previously it had been revealed that the use of e-portfolio had a positive impact on the students' ability to translate. This section mainly discusses the effect of eportfolio use on students' processes of translation. 


\section{Feedback}

From the perception test through questionnaires and interviews it can be concluded that students enjoyed using their e-portfolio since they got more feedback, not only from the lecturer but also from their peers. As a matter of fact, some of the students gave each other detailed and meticulous feedback. They also found it easier to re-access their work and exercises having been done before so that they could see some errors and feedback from the lecturer and friends not to repeat the same mistakes. Using e-portfolios makes it easier for them to share their experiences and knowledge. Unlike conventional assessment techniques, e-portfolios provide space for students to interact with each other to provide input for collective progress. E-portfolios help them develop their ability to work together, criticize the process, and learn to receive input; this is in accordance with the nature of the e-portfolio and the needs of the translation subjects' assessment which emphasizes more on the process rather than the final product. However, some of the students revealed that the lecturer gave more feedback in face-to-face lectures than through e-portfolios. They felt more confident and convinced of their translation if given feedback from the lecturer through e-portfolios as much as they should get in face-toface.

\section{Students' Progress Record}

Using e-portfolios, students also find it easier to track the progress they have achieved. Thus they are easier to plan appropriate way to study according to their shortcomings and feel more confident because they know exactly what to do to improve translation skills. By having the knowledge of personal shortcomings and proper learning planning, students are certainly easier to connect with the learning objective. Ultimately, students are able to develop their skills step by step until the end of the course. They are not only measured by assessments that are capable of measuring the final capabilities but also obtaining judgments depicting the stage of the progress of their abilities. Oneshot assessment is not appropriate, because the ability to translate is a skill requiring continous practice and learning. Based on the results of questionnaires and interviews, it is concluded that students perceived the use of e-portfolio as beneficial in making them become independent learner. They could find the flaws of their own translations by summing up the feedback received. They could exactly understand what to do in order to get a better score because each of their progress is recorded clearly through e-portfolio. 


\section{Flexibility}

The practicality of e-portfolio is very helpful for students in developing their translation ability. They are easier to organize their work and practice. Lecturer could also provide variety of tasks and exercises because the space to provide that previlage is wide open with e-portfolio. Students are abel to do the exercises and the tasks more organized and faster. They did get reluctant by doing every exercise because e-portfolio recorded it well. Lecturer was no longer being burdened by the pile of work sheets since she could access and assess the students' exercise and tasks anywhere and anytime by utilizing technological advances. This is in accordance with the perceptions obtained from interviews and questionnaires. They feel more energized and more interested in doing every exercise and translation task because of the ease of doing the task or exercise through e-portfolio, such as: 1) they could receive diverse feedback from many friends as well as lecturer quickly; 2) they didn't need to write by hand their translations; 3) they could access in a more flexible time; and 4) they could display tasks and exercises in a more interesting way. When using conventional assessments, students were reluctant to do the tasks and translation exercises because they did not have a detailed record of their flaws in translating. But with e-portfolios they could begin to improve their translation skills by looking at the developmental stage of their own capabilities.

\section{DISCUSSION}

The aim of the present study is to investigate the effect of e-portfolio use on the quality of students' translation and their process in translating Indonesian text into English. The study shows that the translations quality is improved after the students used e-portfolio. The accuracy, readability and acceptability of the students' translation are positively improved. The better translation result was supported by the better translation process. The students revealed that since they can access their work collections easier, get much more feedback, spend less time to edit text, and be more excited to show their best work to peers, their translations quality indirectly affected by the use of eportfolio. Such good process lead to a good product, a good translation quality. As Nemati (2016) said, using portfolio can provide a richer picture of students activities. The activities supported the students to feel responsible and motivated to improve their own translating competence. Furthermore, Putra (2011) confirmed that based on his research on how to assess writing that written feedback technique can be used to find out about the students' progress in their writing skill. This statement supported the finding of this research that

Journal on English as a Foreign Language, 8(2), 202-218

Copyright @ 2018 by JEFL, p-ISSN 2088-1657; e-ISSN 2502-6615 
the feedback given both by the lecturer and the peers have positive impact toward the students' translation skill.

Cepik and Yastiban (2013) supported the finding that by using eportfolio the communication between peers and between students and instructor become more effective. The communication effectiveness comes from feedback that students receive in portfolio. The feedback helps students to critically identify and overcome their shortcomings (Cain, Henry, May, \& Joycelyn, 2005). The feedback improves the students` work since it indicates their progress and gives guidance for their future translation. The translating processs which are evidently to be influenced by the use of e-portfolio, in the end helped the students in translating course. The students enjoyed using their e-portfolio since they got more detailed and meticulous feedback, not only from the lecturer but also from their peers.

The more accessible work collection made the students to be more careful in translating and easier to share with peers. Furthermore, by using eportfolio, the students were able to know their progress so it was easier for them to plan appropriate way to study according to their shortcomings. Sewell, Marczak, and Horn (2007) stated that portfolio helps participants involved in examining where they have been and where they want to go. In other words, eportfolio helped the students to be independet learner. E-portfolios can help students help their planning and development since they include the students learning progress (Lin, 2008; Reese \& Levy, 2009). Moreover, it was also concluded that e-portfolio was very practical both for students and teacher.

\section{CONCLUSION}

The current study aims to investigate the effect of e-portfolio use on the quality of students' translation and their process in translating Indonesian text into English. The result of this research shows that the use of e-portfolio is proved to affect the process of students in translating. Influences on the process include the number of feedbacks obtained, the easeness of seeing the progress of their ability to translate, as well as the flexibility in translating and assess it. Furthermore, the use of e-portfolio is also proved to affect the quality of students' translation in the aspect of accuracy, readability, and acceptability.

This study shows that the use of e-portfolio is appropriate to be used in translation courses which assesses learners' skills involving a series of processes that need to be scrutinized at every stage; an assessment which does not only focuses on outcomes but also all the components of the learning process and learning outcomes of learners so as to illustrate the real ability of the learners.

Further research can be done by using a larger number of research subjects so that more data can be obtained. The use of other experimental 
research methods that have a higher level of validity can be used for further research. As mentioned previously, this study does not use a control class. Further research can also be done by examining the effect of e-portfolio use on other translation quality components. Beyond the use of e-portfolio, there are many other methods of assessment that may influence the process and quality of translation. Further research may be carried out to investigate the effect of those methods on the process and quality of translation.

\section{REFERENCES}

Brown, H. D. (2003). Language assessment: Principles and classroom practice. New York: Pearson Education Inc.

Brown, J. D. (2013). New ways of classroom assessment. Alexandria, VA: TESOL.

Cain, M., Henry, E., May, A., \& Joycelyn, R. (2005). Developing portfolios for integrating teaching, learning, and assessment. West Indies: University of the West Indies.

Cepik, S., \& Yastibas A. E. (2013). The use of e-portfolio to improve English speaking skill of Turkish EFL learners. Anthropologist, 16(1-2), 307-317.

Chitpin, S. (2003) Authentic assessment of student work: The use of portfolios. Change: Transformations in Education, 6(1), 70-80.

Coombe, C., Purmensky, K., \& Davidson, P. (2012). Alternative Assessment in Language Education. Cambridge: Cambrige University Press.

Coombe, C., Troudi, S., \& Al-Hamly, M. (2012). Foreign and second language teacher assessment literacy: Issues, challenges, and recommendations. In Coombe, C., Davidson, C. P., O'Sullivan, B., \& SStoynoff, S. (Eds.), The Cambridge Guide to Second Language Assessment (pp. 20-29). Cambridge: Cambridge University Press.

Creswell, J. W. (2012). A concise introduction to mixed methods research. Los Angeles. CA: Sage.

Czura, A. (2013). Implementing portfolio assessment in lower-secondary school. English Language Overseas Perspectives and Enquiries, 10(1), 83-94.

Dudeney \& Hockley. (2007). How to teach English with technology. Essex: Pearson Education.

Farahani, M. V. (2013). The role of discourse analysis in translation. International Journal of Applied Linguistics \& English Literature, 2(1), 112-116.

Ghoorchaei, B., Tavakoli, M., \& Ansari, D. N. (2010). The impact of portfolio assessment on Iranian EFL students' essay writing: A process-oriented approach. GEMA Online Journal of Language Studies, 10(3), 35-51.

Lin, Q. (2008). Preservice teachers' learning experiences of constructing eportfolios online. Internet and Higher Education, 11(3), 194-200. 
Nemati, A. (2016). Portfolio keeping ends to a good product: The cases of reading and motivation. ASIAN TEFL Journal of Language Teaching and Applied Linguistics, 1(2), 187-198.

Putra, S. M. (2011). Appropriate writing assessment how do we do it properly?. Journal of English as a Foreign Language, 1(1), 9-16.

Reese, M., \& Levy, R. (2009). Assessing the future: E-portfolio trends, uses, and options in higher education. ECAR Research Bulletin, 4(1), 1-12.

Sewell, M., Marczak, M., \& Horn, M. (2007). The use of portfolio assessment in evaluation. Tucson: The University of Arizona.

\section{Authors' Brief CV}

Maya Rahmawati is a lecturer of translation course at Universitas Singaperbangsa Karawang (UNSIKA) Indonesia. She holds a master degree specializing in translation. Her research interest are translation teaching, translation criticism, and translation evaluation.

Putri Kamalia Hakim is a lecturer at Universitas Singaperbangsa Karawang (UNSIKA) Indonesia. She has been teaching various subjects in English Education Department. She holds a master degree specializing in second language teaching. Her research interest are second language assessment and the use of ICT in langugae teaching. 